\title{
Assessment of Mercury Concentration in Turtles (Podocnemis unifilis) in the Xingu River Basin, Brazil
}

\author{
Marina Teófilo Pignati ${ }^{1, *}$, Juarez Carlos Brito Pezzuti ${ }^{2}$, Larissa Costa de Souza ${ }^{3}$, \\ Marcelo de Oliveira Lima ${ }^{3}$, Wanderlei Antonio Pignati ${ }^{4}$ and Rosivaldo de Alcântara Mendes ${ }^{3}$ \\ 1 Programa de Pós-graduação em Zoologia, Universidade Federal do Pará e Museu Paraense Emílio \\ Goeldi/CZO, Av. Perimetral, n.1, B. Guamá, Belém, PA 66075-750, Brazil \\ 2 Universidade Federal do Pará, Núcleo de Altos Estudos Amazônicos, Rua Augusto Corrêa, 01, Guamá, \\ Belém, PA 66075-110, Brazil; juarez.pezzuti@gmail.com \\ 3 Instituto Evandro Chagas, Seção de Meio Ambiente, Laboratório de Toxicologia, Rodovia BR 316 km 07, \\ Levilândia, Ananindeua, PA 67010-000, Brazil; laricsouza@gmail.com (L.C.d.S.); \\ marcelolima@iec.pa.gov.br (M.d.O.L.); rosivaldomendes@iec.pa.gov.br (R.d.A.M.) \\ 4 Instituto de Saúde Coletiva, Universidade Federal de Mato Grosso, Av. Fernando Corrêa da Costa, \\ 2367, Boa Esperança, Cuiabá, MT CEP 78060-900, Brazil; pignatimt@gmail.com \\ * Correspondence: marinateofilo@yahoo.com.br; Tel.: +55-96-9811-27595
}

Received: 18 April 2018; Accepted: 7 May 2018; Published: 6 June 2018

\begin{abstract}
Many studies on mercury contamination in aquatic biota deal with the effect of consuming metal-contaminated organisms on human health. In this study, we examined the factors that cause mercury contamination in Podocnemis unifilis in the Xingu River Basin of Mato Grosso and Pará States, Brazil. We quantified by atomic absorption spectroscopy with cold vapor the total mercury (THg) content in the liver and muscle samples of 50 Podocnemis unifilis specimens collected from the basin. The liver and muscle samples contained $134.20 \pm 119.30 \mathrm{ng} \mathrm{g}^{-1} \mathrm{THg}$ and $24.86 \pm 26.36 \mathrm{ng} \mathrm{g}^{-1}$ $\mathrm{THg}$, respectively. Each chelonian or meal has, on average, $5.34 \times$ more $\mathrm{Hg}$ than the highest level established as acceptable. From the results it can be inferred that, given the weekly consumption of chelonians, the riverine and indigenous communities in the Xingu River Basin are at risk of chronic consumption of $\mathrm{Hg}$ in amounts beyond the acceptable limit. The potential high risk to the health of this population is evident; however, the risk classification needs to be further studied.
\end{abstract}

Keywords: mercury; biomonitoring; aquatic toxicology; chelonian; Xingu

\section{Introduction}

Mercury $(\mathrm{Hg})$ is a heavy metal found in both aquatic and terrestrial ecosystems [1,2]. Elevated $\mathrm{Hg}$ concentration is highly toxic, exerting adverse effects on the health of animals and humans $[3,4]$. Mercury poisoning in humans and vertebrate animals decreases their growth rate, blood cell viability, gonadal development, and even causes chronic convulsions or blindness [5-9].

Naturally occurring $\mathrm{Hg}$ in soil and vegetation biomass can be mobilized and its concentration can be elevated through anthropogenic activity. For instance, anthropogenic sources release approximately $1900-2900 \mathrm{Mg}_{\text {year }}{ }^{-1}$ into the atmosphere, whereas the primary natural input is only $80-600 \mathrm{Mg}$ year $^{-1}[10]$.

The Amazonian region has the highest environmental concentration of natural $\mathrm{Hg}$ worldwide [11,12]. In Brazil, natural emission coupled with anthropogenic activities, such as mining, deforestation, and hydroelectric plants have considerably increased $\mathrm{Hg}$ release into the environment [2,13,14]. Moreover, other local environmental factors, such as aquatic $\mathrm{pH}$ and rainfall, influence the distribution of $\mathrm{Hg}[15,16]$.

Studies have demonstrated the extent of $\mathrm{Hg}$ accumulation in humans, animals, soil, and rivers [11,17-21]. Highly persistent, $\mathrm{Hg}$ is biomagnified along the food chain and is present in several aquatic trophic levels [19]. 
As ingesting contaminated food (especially seafood) is a major means of human exposure to $\mathrm{Hg}$, studies have focused on $\mathrm{Hg}$ contamination in aquatic biota [22].

Given their long life span, aquatic turtles can accumulate toxic substances over extended periods and are thus important organisms for monitoring environmental contamination temporally [23-25]. Evidence from studies on turtles reveals that tissue $\mathrm{Hg}$ concentration is linked to variations in growth, size and tissue type [26-28].

Turtles represent an important source of food for Amazonian communities [29-31]. The aquatic turtle Podocnemis unifilis is widespread in the Xingu River Basin in the states of Mato Grosso to Pará [23,32]. Thus, there is a concern regarding how elevated Hg levels will affect the ecology of Podocnemis unifilis and how human consumption of Podocnemis unifilis might increase $\mathrm{Hg}$ exposure and contamination risk.

This study used Podocnemis unifilis as a biomonitor to investigate factors that affect the level of $\mathrm{Hg}$ contamination in five sites of the Xingu River Basin. We aimed to provide insights on a wide range of physical, ecological and anthropogenic factors that can influence environmental contamination and animal exposure risk. In addition to the abiotic variables, we examined whether physical size, sex and tissue type affect $\mathrm{Hg}$ accumulation in turtles.

\section{Materials and Methods}

\subsection{Sampling Sites}

The Xingu River Basin spans 39 municipalities in the states of Mato Grosso and Pará (51 million hectares), covering 20 indigenous lands and 10 conservation areas. Located in an ecotone zone between the Cerrado-Amazônia biomes, the basin begins in Mato Grosso (Upper Xingu) with its mouth in Pará (Lower Xingu). The region has a population of about 610,000 (1.2 inhabitants $\left./ \mathrm{km}^{2}\right)$ that subsists mainly on cattle raising, monoculture, and wood extraction [33]. The study included five sampling points situated along the sources and tributaries of the rivers in the Xingu Basin (Figure 1, Table 1).

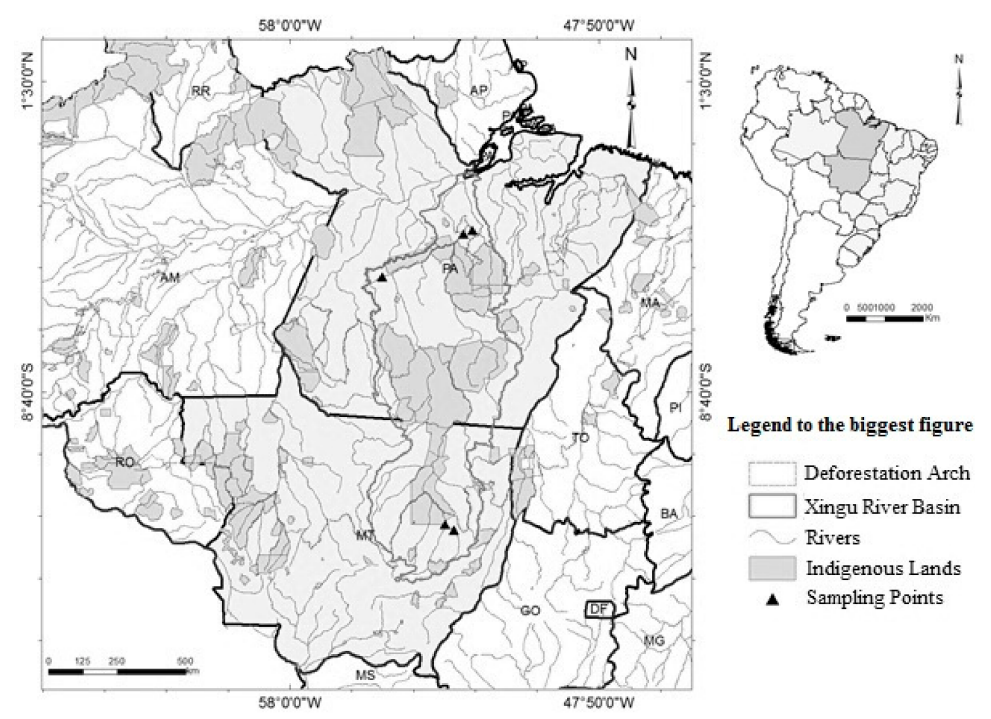

Figure 1. Map of the sampling localities in the Xingu River Basin of Mato Grosso and Pará States, Brazil (black triangles). 
Table 1. Sampling location in the Xingu River Basin of Mato Grosso and Pará States, Brazil.

\begin{tabular}{ccccc}
\hline & & & \multicolumn{2}{c}{ Geographic Coordinates } \\
\hline Code & Municipality & Description & Latitude & Longitude \\
\hline MT1 & Canarana & Sete de Setembro River & $13^{\circ} 10^{\prime} 57.4^{\prime \prime} \mathrm{S}$ & $52^{\circ} 34^{\prime} 35.7^{\prime \prime} \mathrm{W}$ \\
MT2 & Gaúcha do Norte & Culuene River & $12^{\circ} 59^{\prime} 06.4^{\prime \prime} \mathrm{S}$ & $52^{\circ} 52^{\prime} 42.8^{\prime \prime} \mathrm{W}$ \\
PA1 & Altamira & Anfrísio River & $04^{\circ} 53^{\prime} 17.7^{\prime \prime} \mathrm{S}$ & $54^{\circ} 55^{\prime} 57.2^{\prime \prime} \mathrm{W}$ \\
PA2 & Altamira & Belo Monte Hydroelectric Dam & $03^{\circ} 29^{\prime} 10.6^{\prime \prime} \mathrm{S}$ & $52^{\circ} 15^{\prime} 50.2^{\prime \prime} \mathrm{W}$ \\
PA3 & Altamira & Belo Monte Hydroelectric Dam & $03^{\circ} 22^{\prime} 16.6^{\prime \prime} \mathrm{S}$ & $51^{\circ} 57^{\prime} 51.3^{\prime \prime} \mathrm{W}$ \\
\hline
\end{tabular}

\subsection{Animal Collection, Tissue Sampling, and Sample Preparation}

Adult and juvenile turtles were captured during the dry season (October to December) of 2014, corresponding to the turtles' reproductive season. Three methods were employed to capture adult and juvenile turtles. First, we used a hand-net consisting of a wooden rod attached to a small mesh sack via a ring. Second, we used fishing rods equipped with windlasses, and Hoplias spp. and Gymnotus spp. as bait. Finally, the divers manually caught specimens sighted on the water surface.

Ten Podocnemis unifilis individuals per locality were collected, yielding 50 specimens in total. The animals were sexed [32] and biometric data were obtained. The latter included straight carapace length (SCL) and plastron length measured with a pachymeter, as well as mass (g) determined using a scale. The collection of animals was authorized by the Chico Mendes Institute for Biodiversity Conservation No. 44743-1 and the Animal Ethics Committee for the Use of Animals at the Federal University of Pará No. 2661161216. The animals were euthanized in compliance with the guidelines for animal welfare. The muscle and hepatic tissue samples were obtained to avoid any metal contamination and stored in Falcon tubes at $-20{ }^{\circ} \mathrm{C}$ until subsequent analyses.

\subsection{Total Mercury (THg) Determination}

The concentration of total $\mathrm{Hg}(\mathrm{THg})$ in the liver and muscles was analyzed using a previously published protocol [34]. Approximately $0.5 \mathrm{~g}$ of each sample was placed in a $50 \mathrm{~mL}$ volumetric flask, and $1 \mathrm{~mL}$ of deionized water, $2 \mathrm{~mL}$ of nitric acid plus perchloric acid solution (50:50), and $5 \mathrm{~mL}$ of concentrated sulfuric acid were added. The reaction mixture was subsequently heated for $30 \mathrm{~min}$ on a hot plate at $200{ }^{\circ} \mathrm{C}$, cooled, and tested, with deionized water used as control. Furthermore, $5 \mathrm{~mL}$ of sample was subjected twice to cold vapor generation and atomic absorption spectrometry (CV-AAS). A calibration curve was then prepared by the same procedure [34], but altering the mass matrix through different volumes of standard $\mathrm{Hg}$ solution. The limits of detection (LD) and quantification (LQ) were 0.0001 and $0.0005 \mathrm{ng} \mathrm{g}^{-1}$, respectively.

\subsection{Environmental Factors}

Data on hotspots (sites with frequent fires) and deforestation $\left(\mathrm{km}^{2}\right)$ in Mato Grosso and Pará during 2014 were obtained through the Fire Monitoring System of the PRODES project (Program for Calculating the Degree of Deforestation in the Amazon) [35,36]. Rainfall data (mm) for 2014 were obtained from the National Water Agency database [37]. For each body of water, the latitude was recorded, and $\mathrm{pH}$ at the time of sample collection was recorded using a $\mathrm{pH}$ field meter.

\subsection{Statistical Analysis}

Permutation tests for multivariate analysis of variance (PERMANOVA) were conducted to determine whether the $\mathrm{THg}$ concentration varied with the tissue type in Podocnemis unifilis. A similarity matrix based on Bray-Curtis Index was produced and $\log (X+1)$ transformed for analysis, with 9999 permutations. A principal coordinates $(P C O)$ analysis was performed to determine the tissue with the highest THg contamination. The analyses were conducted in PRIMER version 6 [38] with PERMANOVA+1 added [39]. 
The SCL, plastron length, and body weight correlated significantly (Pearson's $r \geq 0.95, p<0.05$ ). Thus, only SCL was used in the subsequent statistical analyses. A covariance analysis (ANCOVA) was employed to examine the changes in the THg concentrations with body size and sex for each sampled tissue (sex and SCL of sampled turtles were entered as covariables). These analyses were conducted in Statistica version 10.0 [40].

Among the environmental variables, hotspot and deforestation were highly correlated (0.98), so were rainfall and latitude (0.91) $(p<0.05)$. Thus, only hotspot, rainfall, and $\mathrm{pH}$ were used in the multiple regression analysis on how the $\mathrm{THg}$ varied in each sampled tissue with environmental factors. These analyses were also conducted in Statistica.

A second PERMANOVA was performed for each sampled tissue to determine between-locality differences in the THg concentration. A Bray-Curtis-based similarity matrix was produced and $\log (X+1)$ transformed with 9999 residual permutations in PRIMER version 6 with PERMANOVA+1. Significance was set at $p<0.05$ for all analyses.

\section{Results}

\subsection{Specimen Characterization}

Table 2 shows the morphometrics of the sampled turtles.

Table 2. Distribution of sampled Podocnemis unifilis individuals by sex and body size.

\begin{tabular}{cccc}
\hline & $\boldsymbol{N}$ & SCL $\mathbf{( c m )}$ & Weight $(\mathbf{k g})$ \\
\hline $\mathbf{M}$ & 28 & $24.4 \pm 4.0(17.8-27.8)$ & $1.525 \pm 0.788(0.600-2.100)$ \\
$\mathbf{F}$ & 22 & $25.6 \pm 4.1(22.8-33.2)$ & $1.758 \pm 0.814(1.200-3.800)$ \\
Total & 50 & $25.5 \pm 4.0(17.8-33.2)$ & $1.717 \pm 0.790(0.600-3.800)$ \\
\hline
\end{tabular}

$\mathrm{M}=$ male; $\mathrm{F}$ = female; average values \pm standard deviation (minimum-maximum); SCL (straight carapace length).

\subsection{THg Concentrations across Tissues}

The mean THg concentration (and range) in the liver and muscle was $134.20 \pm 119.39$ (24.23-804.21 $\mathrm{ng} \mathrm{g}^{-1}$ ) and $24.86 \pm 26.36 \mathrm{ng} \mathrm{g}^{-1}\left(7.40-188.04 \mathrm{ng} \mathrm{g}^{-1}\right)$, respectively.

The concentration of $\mathrm{Hg}$ was significantly higher in the liver than in muscle (pseudo- $\mathrm{F}_{(1,98)}=165.06$, $p<0.001)$. The PCO results identified two axes that accounted for $99.9 \%$ of the THg variation in both the tissues $(\mathrm{PCO} 1=96.4 \%$ and $\mathrm{PCO} 2=3.5 \%$ ) (Figure 2 ).

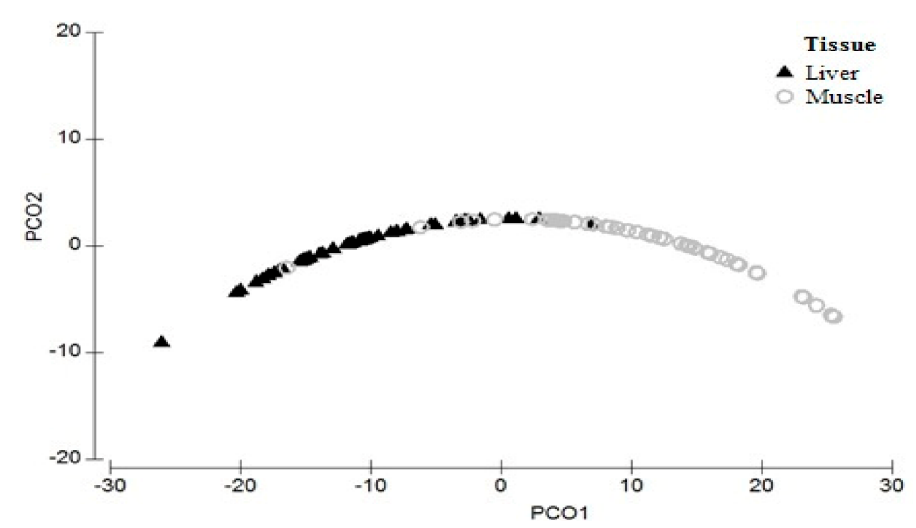

Figure 2. Principal coordinates analysis (PCO) of $\mathrm{THg}$ concentration $\left(\mathrm{ng} \mathrm{g}^{-1}\right)$ in the liver (black triangle) and muscle (grey circle) of Podocnemis unifilis. 


\subsection{Sex- and Size-Based Differences in THg Level}

Female and male Podocnemis unifilis did not differ significantly with respect to concentrations of THg $\left(\mathrm{ng} \mathrm{g}^{-1}\right)$. The liver and muscle of male Podocnemis unifilis contained 136.48 and $24.70 \mathrm{ng} \mathrm{g}^{-1}$ $\mathrm{THg}$, respectively, whereas that of female Podocnemis unifilis contained 138.04 and $25.77 \mathrm{ng} \mathrm{g}^{-1}$, respectively. Overall, neither the sex nor SCL significantly influenced the concentration of THg in the liver (ANCOVA, $\left.\mathrm{F}_{(1,46)}=0.351, p<0.556\right)$ or muscle $\left(\mathrm{F}_{(1,46)}=2.205, p<0.144\right)$ of Podocnemis unifilis. Although no differences were found in the concentration of THg between the liver and muscle of Podocnemis unifilis, we found that the female with the highest SCL $(33.2 \mathrm{~cm})$ had a higher concentration of THg in the liver (253.96 $\left.\mathrm{ng} \mathrm{g}^{-1}\right)$ and muscle (188.04 $\left.\mathrm{ng} \mathrm{g}^{-1}\right)$.

\subsection{Influence of Environmental Factors on THg Level}

The environmental variables, including hotspots, rainfall, and $\mathrm{pH}$, had no influence on the concentration of THg in the liver (multiple regression, $R^{2}=0.099, \mathrm{~F}_{(3,46)}=1.6964, p<0.180$ ) or muscle $\left(R^{2}=0.569, \mathrm{~F}_{(3,46)}=0.9258, p<0.435\right)$.

\subsection{Spatial Distribution of $\mathrm{THg}$}

The spatial analysis indicated that hepatic THg concentration was the highest $\left(188.41 \mathrm{ng} \mathrm{g}^{-1}\right)$ at PA3, located near the Belo Monte hydroelectric dam. Muscle THg concentration was the highest $\left(36.35 \mathrm{ng} \mathrm{g}^{-1}\right.$ ) at MT1 in the Sete de Setembro River, a source of the Xingu River. The turtle with the highest THg concentration (804.21 $\mathrm{ng} \mathrm{g}^{-1}$ ) was also found in PA3. The lowest average hepatic THg concentration (77.31 $\mathrm{ng} \mathrm{g}^{-1}$ ) was recorded at MT2 in the Culene River, also near the source of the Xingu River, whereas the lowest muscle $\mathrm{THg}$ concentration $\left(15.89 \mathrm{ng} \mathrm{g}^{-1}\right)$ was measured at PA1 in the Anfrísio River of Pará.

Overall, the concentration of THg did not vary significantly between the sampling localities (Figure $3 \mathrm{a}, \mathrm{b}$ ), either in the liver (PERMANOVA, pseudo- $\mathrm{F}_{(4,45)}=1.4982, p<0.2103$ ) or muscle (pseudo- $\left.\mathrm{F}_{(4,45)}=1.1424, p<0.3417\right)$.
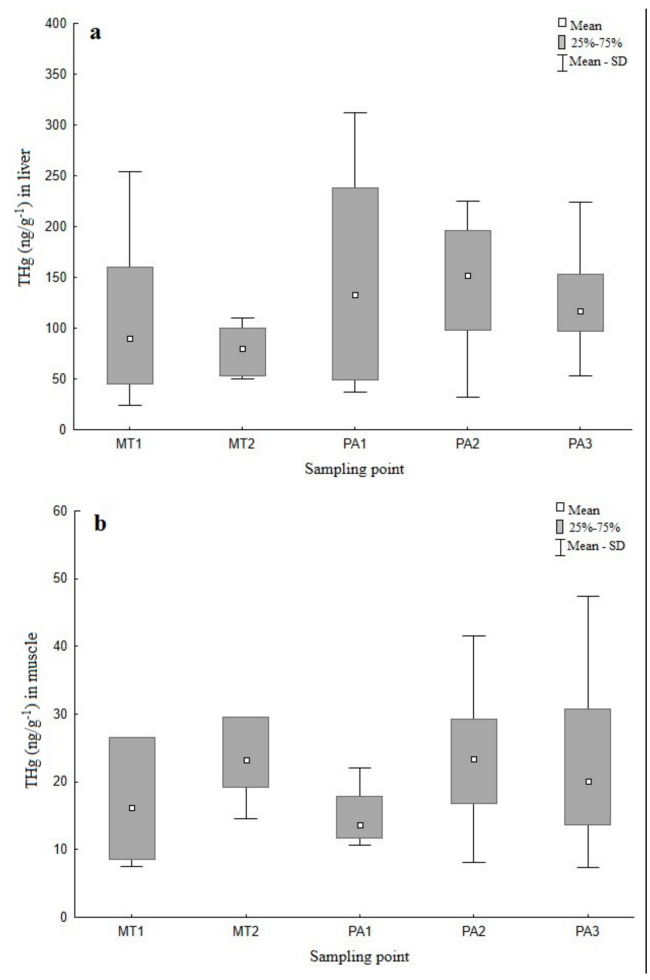

Figure 3. Total mercury concentration $(\mathrm{THg})\left(\mathrm{ng} \mathrm{g}^{-1}\right)$ in the liver (a) and muscle (b) of Podocnemis unifilis across sampling localities. 


\section{Discussion}

Mercury was detected in all tissue samples at varying concentrations. However, the concentrations observed were less than the levels reported in previous studies on turtle species, except those carried out in the Xingu Basin.

Souza-Araújo et al. [28] reported a concentration of $20 \mathrm{ng} \mathrm{g}^{-1} \mathrm{THg}$ in the muscle samples of Podocnemis unifilis in the Xingu Basin, state of Pará. This is similar to the findings of the present study. However, several studies, including studies in the Amazon region, reported concentrations higher than that observed in the present study (Table 3); this can be accounted for by the fact that some of these studies were conducted with species at different trophic levels and in different geographic regions worldwide.

Table 3. Published data on mercury $(\mathrm{Hg})$ concentration in turtles.

\begin{tabular}{|c|c|c|c|}
\hline \multirow{2}{*}{ Species } & \multicolumn{2}{|c|}{ Concentration of $\mathrm{Hg}\left(\mathrm{ng} \mathrm{g}^{-1}\right)$} & \multirow{2}{*}{ Reference } \\
\hline & Liver & Muscle & \\
\hline Chelodina parkeri & 593 & 329 & [41] \\
\hline Chelus fimbriata & - & 432 & [21] \\
\hline Chelydra serpentina & $50-500$ & - & [24] \\
\hline Chelydra serpentina & - & 48.1 & [42] \\
\hline Heosemys spinosa & 137.9 & 10 & [41] \\
\hline Leucocephalon yuwonoi & 78 & 4 & [41] \\
\hline Malaclemys terrapin & 149.3 & 54 & [41] \\
\hline Peltocephalus dumerilianus & - & 106 & {$[21]$} \\
\hline Podocnemis erythrocephala & 470 & 33 & [20] \\
\hline Podocnemis erythrocephala & - & 33 & [21] \\
\hline Podocnemis expansa & - & 62 & [21] \\
\hline Podocnemis expansa & - & 1 & [43] \\
\hline Podocnemis sextuberculata & - & 61 & [21] \\
\hline Podocnemis unifilis & - & 34 & [21] \\
\hline Podocnemis unifilis & - & 1 & [43] \\
\hline Podocnemis unifilis & - & 20 & [28] \\
\hline Podocnemis unifilis & 134.20 & 24.86 & Present study \\
\hline
\end{tabular}

Since the 1960s, anthropogenic activities, such as mining, deforestation, and site burning, in northern Mato Grosso and Pará (Amazon region) have elevated the level of $\mathrm{Hg}$ emissions into the atmosphere. Therefore, $\mathrm{Hg}$ has gradually penetrated different habitats [44]. Even today, numerous illegal mining ventures continue to operate across the region, including indigenous lands and conservation zones of the Xingu River Basin in Pará. These activities, which cannot be mapped easily or effectively [33], lead to unchecked distribution of $\mathrm{Hg}$ throughout the basin, thus increasing the level of $\mathrm{Hg}$ that possibly contaminates aquatic organisms, such as Podocnemis unifilis.

The liver tends to accumulate high concentrations of toxic substances because it is an organ with high metabolic activity. Thus, it accumulates more metals than organs with low metabolic activity (such as muscle) [45]. The results of the present and previous studies indicate that the concentration of $\mathrm{Hg}$ is higher in the liver than in the muscle of several aquatic turtle species [20,28,41]. The reptilian liver is known to metabolize and store foreign chemical compounds (xenobiotics). These residues can accumulate to toxic levels if not excreted effectively [46]. Additionally, as detoxification systems in reptiles are less efficient than those in the endothermic organisms, the determination of potential toxicity must also consider how the reptiles metabolize xenobiotics [46].

\subsection{Influence of Sex and Body Size on THg Level}

Several studies have reported positive correlations between body size and $\mathrm{Hg}$ concentration in aquatic turtles, including Chelydra serpentina [24], Chelodina parkeri, Heosemys spinosa, Leucocephalon yuwonoi, Malaclemys terrapin [41], Podocnemis erythrocephala [20], and Podocnemis unifilis [43]. 
Among Chelydra serpentina, Sternotherus odoratus, Chrysemys picta, and Pseudemys rubriventris, the older and larger individuals tend to have proportionally higher $\mathrm{Hg}$ concentrations than the younger and smaller individuals [27]. This pattern probably occurred because $\mathrm{Hg}$ continually bioaccumulates over time or because the animals change their feeding habits as they increase in size. However, in the present study, we noted that although the morphometric measures can predict longevity, reptilian growth patterns are not always straightforward to interpret and should be treated with caution [47]. Several studies did not observe sex differences in total $\mathrm{Hg}$ concentration among aquatic turtles [21,27,28,41]. However, sex differences in the accumulation of contaminants are actually common in reptiles [26]. Such variations likely occur among reptiles because the females eliminate a portion of accumulated metals through egg laying. Other behavioral variations between the males and females might also explain differences in bioaccumulation. The female turtles also tend to be heavy, increasing the likelihood of organometal accumulation, thus altering the degree of exposure between sexes [48].

\subsection{Influence of Environmental Factors on $\mathrm{THg}$ Level}

Mercury contamination results from a combination of naturally occurring and anthropogenically produced Hg. In this study, we did not find a correlation between the THg concentration in Podocnemis unifilis and measured environmental variables or site locality. However, previous studies have suggested that the accumulation of $\mathrm{Hg}$ in the Amazonian animals reflects the bioavailability of metals in the environment [17].

The findings of this study are in line with those of previous studies [20,42], showing that the water $\mathrm{pH}$ is not correlated with the concentration of $\mathrm{Hg}$ in P. erythrocephala and C. serpentina, although environmental changes (including $\mathrm{pH}$ fluctuation) can alter mercury bioavailability. Methylation decreases with decrease in the water $\mathrm{pH}$, therefore methylmercury is more likely to be present in areas with low $\mathrm{pH}$, leading to its bioaccumulation throughout the food chain $[15,16,49]$. Clear rivers, such as the Xingu River and its tributary Iriri, are acidic (4.5-7.8), suggesting that $\mathrm{Hg}$ concentration in Podocnemis unifilis should also be high. However, as mentioned earlier, this was not the case in this study. The lack of significant variation in $\mathrm{pH}$ across the sampled water bodies might be a reason for this apparent contradiction.

The Amazon Basin is estimated to emit 6-8 tons of $\mathrm{Hg}$ per year due to burning forests [50]. As $\mathrm{Hg}$ does not mix with ash, precipitation causes the metal to exit soil as leachates that flow into bodies of water [51]. In the Xingu River and its tributary Iriri, a small amount of light material tends to be suspended in the water [49], and heavy rainfall benefits this process. Thus, we expected that burning forests and precipitation should influence $\mathrm{Hg}$ contamination in Podocnemis unifilis. However, we did not observe any evidence of this in this study. Our findings might reflect a generalized pattern of contamination affecting the Xingu Basin and possibly other sub-basins in the Amazon region. This overall trend is likely due to multiple anthropogenic activities that are also linked to naturally occurring $\mathrm{Hg}$ in the soil and ecosystem.

\subsection{Spatial Distribution of $\mathrm{THg}$}

Our results revealed that the overall highest average $\mathrm{THg}$ concentration and also the turtle with the highest $\mathrm{THg}$ concentration in the liver were found at PA3, located near the Belo Monte hydroelectric dam. Thus, the proximity of individuals to this hydroelectric dam might have resulted in a high level of $\mathrm{THg}$ in turtles.

Hydroelectric dams are one of the anthropogenic features that can increase $\mathrm{Hg}$ contamination in Podocnemis unifilis and elevate Hg exposure risk among the communities in the Xingu consuming these turtles. The dams increase methylmercury production by slowing down water flow upstream, thus allowing $\mathrm{Hg}$ accumulation and mixing with the river-bottom sediment. Eventually, $\mathrm{Hg}$ and sediment tend to separate in the dam reservoir. Simultaneously, anoxic conditions in the dams cause methanogenic bacteria to proliferate, increasing methylmercury production and elevating contamination risk throughout the food chain [52]. Currently, the operational dams in the Amazon 
Basin include the Paranatinga II, Culuene, and Ronuro hydroelectric dams in Mato Grosso, as well as the Belo Monte hydroelectric dam in Pará. These structures potentially spread $\mathrm{Hg}$ contamination in aquatic life in the Xingu River Basin and hence in the inhabitants of the surrounding regions.

\subsection{Evaluation of Risk to Human Consumers of Turtles}

Food consumption is the main source of human exposure to contaminants, representing a fundamental component of health risk assessment [53-55]. The exposure to chemical substances in the diet can be chronic or acute, with chronic exposure characterized by the ingestion of small quantities of a substance over a long period and acute exposure by the ingestion of large quantities during an interval of up to $24 \mathrm{~h} \mathrm{[56].}$

The chelonians of the genus Podocnemis represent an important source of diet of the Amazonian population, with the consumption of one individual of these species per meal/week/person in the Parque Nacional do Jaú, in the state of Amazonas, as well as in the Bolivian Amazon [29,57]. With the communities in the Amazon still consuming chelonians [29], it is important to establish safe consumption limits of this protein resource.

To analyze the health risk, Green et al. [41] was referenced regarding the acceptable limit of $\mathrm{Hg}$ in chelonians because these authors adapted the limits set by United States Environmental Protection Agency (EPA) and the Food and Drug Administration (FDA). They have established an acceptable daily intake of $\mathrm{Hg}$ in fish. Based on their study by Green et al. [41], which also established the consumption limit of $1900 \mathrm{ppb} \mathrm{Hg}$ for a meal of $277 \mathrm{~g}$ of chelonian, i.e., $6.86 \mathrm{ng}$ of mercury per gram of edible part of the turtle (muscle and liver), we evaluated the potential risk of $\mathrm{Hg}$ by the consumption of the chelonians sampled in this study.

According to Rodrigues et al. [58] and Luz et al. [59], the body weight of Podocnemis spp. is equivalent to $24.1 \%$ of muscle tissue and $2.90 \%$ of liver based on the total body weight. In the present study, the average body weight of the turtles was $1.717 \mathrm{~g}$; thus, the average weight of muscle and liver of each chelonian was $414 \mathrm{~g}$ and $50 \mathrm{~g}$, respectively. The results showed that the average amount of $\mathrm{Hg}$ in $1 \mathrm{~g}$ of muscle is $24.86 \mathrm{ng}$ and in $1 \mathrm{~g}$ of liver is $134.20 \mathrm{ng}$ of $\mathrm{Hg}$. Thus, it was found that a chelonian on average contains 17,002 $\mathrm{ng} \mathrm{Hg}$ or $36.62 \mathrm{ng} \mathrm{g}^{-1} \mathrm{Hg}$ in its edible parts (muscle and liver). Consequently, each chelonian or meal consisted of, on average, $5.34 \times$ more $\mathrm{Hg}$ than the highest level established for Green et al. [41] by the EPA.

From the results it can be inferred that, given their weekly consumption of chelonians, the riverine and indigenous communities in the Xingu River Basin are at risk of chronic uptake of mercury in amounts beyond the acceptable limit. Thus, the potential high risk of $\mathrm{Hg}$ to the health of this population is evident; however, the risk classification needs further studies.

Thus, turtle meat is frequently consumed by the riverside and indigenous communities in the Xingu River Basin, indicating that these communities are at a risk of suffering health problems related to $\mathrm{Hg}$ exposure.

\section{Conclusions}

All turtle tissue samples exhibited detectable concentrations of $\mathrm{THg}$, with the liver containing $\mathrm{THg}$ levels significantly higher than that of muscles. Neither sex nor body size significantly influenced the concentration of THg in turtles. Similarly, the measured environmental factors did not affect the concentration of THg. This species is becoming an important biomonitor of environmental quality and $\mathrm{Hg}$ exposure risk. Furthermore, Podocnemis unifilis is a popular source of food for the native communities in the Xingu River Basin. Each chelonian or meal has, on average, $5.34 \times$ more $\mathrm{Hg}$ than the highest level established as acceptable. Given the weekly consumption of chelonians, the riverine and indigenous communities in the Xingu River Basin are at risk of chronic consumption of mercury in amounts beyond the acceptable limit. We strongly recommend further studies to empirically determine the level of $\mathrm{Hg}$ in river sediment, air, soil, and riverside human inhabitants. 
Author Contributions: M.T.P. planned and executed the study, analyzed the data and wrote the manuscript; L.C.d.S. performed the experiments in the laboratory; R.d.A.M. and M.d.O.L. helped in planning the experiments in the laboratory and substantively revised the manuscript; W.A.P. and J.C.B.P. planned the study, helped in writing the manuscript, and approved the submitted version.

Funding: This research was funded by the CAPES [Foundation for the Improvement of Personnel in Higher Education] "Governance, Management and Conflicts and the Handling of Natural Resources in the Amazon Region".

Acknowledgments: We would like to thank the Laboratory of Environmental Toxicology at the Evandro Chagas Institute (IEC), Ananindeua-PA for logistical support during the project. We also thank the CAPES [Foundation for the Improvement of Personnel in Higher Education] "Governance, Management and Conflicts and the Handling of Natural Resources in the Amazon Region" for financial support. M.T.P. is grateful to the Chico Mendes Institute for Biodiversity Conservation (ICMBio) of Altamira-PA and the Socio-Environmental Institute (ISA) of Altamira-PA for assistance with fieldwork. Additionally, M.T.P. would like to thank the Federal University of Pará (UFPA) and Paraense Emílio Goeldi Museum (MPEG) for academic and logistical support. This article is a part of M.T.P.'s Doctoral Thesis in Zoology.

Conflicts of Interest: The authors declare no conflict of interest.

\section{References}

1. Haines, T.A.; Komov, V.T.; Matey, V.E.; Jagoe, C.H. Peach mercury content is related to acidity and color of 26 Russian lakes. Water Air Soil Pollut. 1995, 85, 823-828. [CrossRef]

2. Lacerda, L.D. Effect of land use change on the mercury distribution is soils from Alta Floresta, southern Amazon. Environ. Pollut. 2004, 129, 247-255. [CrossRef] [PubMed]

3. Dallinger, R.; Rainbow, P.S. Ecotoxicology of Metals in Invertebrates; Lewin Publishers: Boca Raton, FL, USA, 1993.

4. Akagi, H.; Malm, O.; Kinjo, Y.; Harada, M.; Branchesb, F.J.P.; Pfeifferb, W.C.; Kate, H. Methylmercury pollution in the Amazon, Brazil. Sci. Total Environ. 1995, 175, 85-95. [CrossRef]

5. Wobeser, G.; Nielsen, N.; Schiefer, B. Mercury and Mink. II. Experimental methyl mercury intoxication. Can. J. Comp. Med. 1976, 40, 34-45. [PubMed]

6. Bazar, M.; Holtzman, D.; Adair, B.; Gresens, S. Effects of dietary methylmercury in juvenile corn snakes (Elaphe guttata). In Proceedings of the SETAC 23 Annual Meeting, Salt Lake City, UT, USA, 16-20 November 2002.

7. Day, R.D.; Segars, A.L.; Arendt, M.D.; Lee, A.M.; Peden-Adams, M.M. Relationship of blood mercury levels to health parameters in the loggerhead sea turtle (Caretta caretta). Environ. Health Perspect. 2007, 115, 1421-1428. [CrossRef] [PubMed]

8. Hammerschmidt, C.R.; Sandheinrich, M.B.; Weiner, J.G.; Rada, R.G. Effects of dietary methylmercury on reproduction of fathead minnows. Environ. Sci. Technol. 2002, 36, 877-923. [CrossRef] [PubMed]

9. Schneider, L.; Maher, W.; Green, A.; Vogt, R.C. Mercury contamination in reptiles: An emerging problem with consequences for wild life and human health. In Mercury: Sources, Applications and Health Impacts; Ki-Hyun, K., Richard, J.C.B., Eds.; Nova Science Publishers: Hauppauge, NY, USA, 2013; Chapter 9; pp. 173-232. ISBN 978-1-62257-721-7.

10. Driscoll, C.T.; Mason, R.P.; Chan, H.M.; Jacob, D.J.; Pirrone, N. Mercury as a global pollutant: Sources, pathways, and effects. Environ. Sci. Technol. 2013, 47, 4967-4983. [CrossRef] [PubMed]

11. Fadini, P.S.; Jardim, W.F. Is the Negro River Basin (Amazon) impacted by naturally occurring Hg? Sci. Total Environ. 2001, 275, 71-82. [CrossRef]

12. Wasserman, J.C.; Hacon, S.; Wasserman, M.A. Biogeochemistry of mercury in the Amazonian. Ambio 2003, 32, 336-342. [CrossRef] [PubMed]

13. Veiga, M.M.; Meech, J.A.; Onate, N. Deforestation: A major source of mercury pollution in the Amazon. Nature 1994, 368, 816-817. [CrossRef] [PubMed]

14. Milhomem-Filho, E.O.; Oliveira, C.S.B.; Silveira, L.C.L.; Cruz, T.M.; Souza, G.S.; Costa Junior, J.M.F.; Pinheiro, M.C.N. A ingestão de pescado e as concentrações de mercúrio em famílias de pescadores de Imperatriz (MA). Rev. Bras. Epidemiol. 2016, 19, 14-25. [CrossRef] [PubMed]

15. Guimarães, J.R.D.; Meili, M.; Hylander, L.D.; Silva, E.D.E.; Roulet, M.; Mauro, J.B.N.; De Lemos, R.A. Mercury net methylation in five tropical flood plain regions of Brazil: High in the root zone of floating macrophyte mats but low in surface sediments and flooded soils. Sci. Total Environ. 2000, 261, 99-107. [CrossRef] 
16. Belger, L.; Forsberg, B.R. Factors controlling Hg levels in two predatory fish species in the Negro river basin, Brazilian Amazon. Sci. Total Environ. 2006, 367, 451-459. [CrossRef] [PubMed]

17. Roulet, M.; Lucotte, M.; Rheault, I.; Guimarães, J.R.D. Methylmercury in the water, seston and epiphyton of an Amazonian River and its floodplain, Tapajós River, Brazil. Sci. Total Environ. 2000, 261, 43-59. [CrossRef]

18. Barbosa, A.C.; Jardim, W.; Dórea, J.G.; Fosberg, B.; Souza, J. Hair Mercury speciation as a function of gender, age, and body mass index in inhabitants of the Negro River Basin, Amazon, Brazil. Arch. Environ. Contam. Toxicol. 2001, 40, 439-444. [CrossRef] [PubMed]

19. Kasper, D.; Palermo, E.F.A.; Branco, C.W.C.; Malm, O. Evidence of elevated mercury levels in carnivorous and omnivorous fishes downstream from an Amazon reservoir. Hydrobiologia 2012, 694, 87-98. [CrossRef]

20. Schneider, L.; Belger, L.; Burger, J.; Vogt, R.C. Mercury bioacumulation in four tissues of Podocnemis erythrocephala (Podocnemididae: Testudines) as a function of water parameters. Sci. Total Environ. 2009, 407, 1048-1054. [CrossRef] [PubMed]

21. Schneider, L.; Belger, L.; Burger, J.; Vogt, R.C.; Ferrara, C.R. Mercury levels in muscle of six species of turtles eaten by people along the Rio Negro of the Amazon basin. Arch. Environ. Contam. Toxicol. 2010, 58, 444-450. [CrossRef] [PubMed]

22. Kasper, D.; Forsberg, B.R.; Amaral, J.H.F.; Leitao, R.P.; Py-Daniel, S.S.; Bastos, W.R.; Malm, O. Reservoir stratification affects methylmercury levels in river water, plankton, and fish downstream from Balbina hydroelectric dam, Amazonas, Brazil. Environ. Sci. Technol. 2014, 48, 1032-1040. [CrossRef] [PubMed]

23. Ernst, C.H.; Barbour, R.W. Turtles of the World; Smithsonian Institution Press: Washington, WA, USA, 1989.

24. Golet, W.J.; Haines, T.A. Snapping turtles (Chelydra serpentina) as monitors for mercury contamination of aquatic environments. Environ. Monit. Assess. 2001, 71, 211-220. [CrossRef] [PubMed]

25. Storelli, M.M.; Marcotrigiano, G.O. Heavy metal residues in tissues of marine turtles. Mar. Pollut. Bull. 2003, 46, 397-400. [CrossRef]

26. Burger, J.; Campbell, K.R.; Campbell, T.S. Gender and spatial patterns in metal concentrations in brown anoles (Anolis sagrei) in southern Florida, USA. Environ. Toxicol. Chem. 2004, 23, 712-718. [CrossRef] [PubMed]

27. Bergeron, C.M.; Usak, J.F.H.; Unrine, J.M.; Romanek, C.S.; Hopkins, W.A. Influence of feeding ecology on blood mercury concentrations in four species of turtles. Environ. Toxicol. Chem. 2007, 26, 1733-1741. [CrossRef] [PubMed]

28. Souza-Araujo, J.; Giarrizzo, T.; Lima, M.O. Mercury concentration in different tissues of Podocnemis unifilis (Troschel, 1848) (Podocnemididae: Testudines) from the lower Xingu River-Amazonian, Brazil. Braz. J. Biol. 2015, 75 (Suppl. 1), S106-S111. [CrossRef] [PubMed]

29. Rebêlo, G.H.; Pezzuti, J. Percepções sobre o consumo de Quelônios na Amazônia. Ambient. Soc. 2000, 6, 85-104. [CrossRef]

30. Pantoja-Lima, J.; Braga, T.M.; Félix-Silva, D.; Pezzuti, J.C.; Rebelo, G.H. Mapeamento participativo do uso dos recursos naturais e conhecimento tradicional sobre ecologia de quelônios na várzea do Rio Purus, Brasil. Pap. NAEA 2012, 294, 3-24.

31. Pantoja-Lima, J.; Aride, P.H.R.; Oliveira, A.T.; Félix-Silva, D.; Pezzuti, J.C.B.; Rebêlo, G.H. Chain of commercialization of Podocnemis spp. turtles (Testudines: Podocnemididae) in the Purus River, Amazon basin, Brazil: Current status and perspectives. J. Ethnobiol. Ethnomed. 2014, 10, 8. [CrossRef] [PubMed]

32. Rueda-Almonacid, J.V.; Carr, J.L.; Mittermeier, R.A.; Rodrigues-Mahecha, J.V.; Mast, R.B.; Vogt, R.C.; Rhodin, A.G.J.; De La Ossa-Velasquez, J.; Rueda, J.N.; Mittermeier, C.G. Las Tortugas e Cocodrilianos de los Países Andinos e Del Trópico; Conservación Internacional: Bogotá, Colombia, 2007.

33. Villas-Bôas, A. De Olho na Bacia do Xingu (Série Cartô Brasil Socioambiental, n. 5); Instituto Socioambiental: São Paulo, Brazil, 2012.

34. Akagi, H.; Suzuki, T.; Arimura, K.; Ando, T.; Sakamoto, M.; Satoh, H.; Naganuma, A.; Futatsuka, M.; Matsuyama, A. Mercury Analysis Manual; Ministry of the Environment: Chiyoda, Japan, 2004.

35. INPE-Instituto Nacional de Pesquisas Espaciais. Sistema de Monitoramento de Queimadas por Satélites. 2016. Available online: http:/ / www.dpi.inpe.br/proarco/bdqueimadas (accessed on 1 February 2016).

36. INPE—Instituto Nacional de Pesquisas Espaciais. Desmatamento nos Municípios, Projeto PRODES. 2016. Available online: http:/ / www.dpi.inpe.br/prodesdigital/prodesmunicipal.php (accessed on 2 February 2016).

37. Agência Nacional de Águas (ANA). HidroWeb: Sistemas de Informações Hidrológicas. 2016. Available online: http:/ / hidroweb.ana.gov.br/HidroWeb (accessed on 1 January 2016).

38. Clarke, K.R.; Gorley, R.N. Software PRIMER v5; PRIMER-E: Plymouth, UK, 2006. 
39. Anderson, M.J.; Gorley, R.N.; Clarke, K.R. PERMANOVA+ for PRIMER: Guide to Software and Statistical Methods; PRIMER-E: London, UK, 2008.

40. StatSoft, Inc. STATISTICA (Data Analysis Software System), Version 10. 2011. Available online: http:/ / www. statsoft.com (accessed on 22 February 2015).

41. Green, A.D.; Buhlmann, K.A.; Hagen, C.; Romanek, C.; Gibbons, J.W. Mercury contamination in turtles and implications for human health. J. Environ. Health 2010, 72, 14-22. [PubMed]

42. Turnquist, M.A.; Driscoll, C.T.; Schulz, K.L.; Schlaepfer, M.A. Mercury concentrations in snapping turtles (Chelydra serpentina) correlate with environmental and landscape characteristics. Ecotoxicology 2011, 20, 1599-1608. [CrossRef] [PubMed]

43. Eggins, S.; Schneider, L.; Krikowa, F.; Vogt, R.C.; Da Silveira, R.; Maher, W. Mercury concentrations in different tissues of turtle and Caiman species from the Rio Purus, Amazonas, Brazil. Environ. Toxicol. Chem. 2015, 34, 2771-2781. [CrossRef] [PubMed]

44. Santos, E.C.O.; Jesus, I.M.; Brabo, E.S.; Fayal, K.F.; Sá-Filho, G.C.; Lima, M.O.; Miranda, A.M.M.; Mascarenhas, A.S.; Sá, L.L.C.; Silva, A.P.; et al. Exposição ao mercúrio e ao arsênio em Estados da Amazônia: Síntese dos estudos do Instituto Evandro Chagas/FUNASA. Rev. Bras. Epidemiol. 2003, 6, 171-185. [CrossRef]

45. Kalay, M.; Ay, Ö.; Canli, M. Heavy metal concentrations in fish tissues from the Northeast Mediterranean Sea. Bull. Environ. Contam. Toxicol. 1999, 63, 673-681. [CrossRef] [PubMed]

46. Gardner, S.C.; Oberdörster, E. (Eds.) Toxicology of Reptiles; CRC Press: Boca Raton, FL, USA, 2005.

47. Pfennig, D.W.; Mabry, A.; Orange, D. Environmental causes of correlations between age and size at metamorphosis in Scaphiopus multiplicatus. Ecology 1991, 72, 2240-2248. [CrossRef]

48. Meyers-Schone, L.; Walton, B.T. Turtles as monitors of chemical contaminants in the environment. Rev. Environ. Contam. Toxicol. 1994, 135, 93-153. [CrossRef]

49. Salati, E.; Junk, W.J.; Shubart, H.O.R.; Oliveira, A.E. Amazônia: Desenvolvimento, Integração e Ecologia; Conselho Nacional de Desenvolvimento Científico e Tecnológico: São Paulo, Brazil, 1983.

50. Roulet, M.; Lucotte, M.; Farella, N.; Serique, G.; Coelho, E.; Passos, C.J.S.; Silva, E.J.; Andrade, P.S.; Mergler, D.; Guimarães, J.R.D.; et al. Effects of recent human colonization on the presence of mercury in Amazonian ecosystems. Water Air Soil Pollut. 1999, 112, 297-313. [CrossRef]

51. Fostier, A.H.; Forti, M.C.; Guimarães, J.R.; Melfi, A.J.; Boulet, R.; Espirito Santo, C.M.; Krug, F.J. Mercury fluxes in a natural forested Amazonian catchment (Serra do Navio, Amapá State, Brazil). Sci. Total Environ. 2000, 260, 201-211. [CrossRef]

52. Castello, L.; Macedo, M.N. Large-scale degradation of Amazonian freshwater Ecosystems. Glob. Chang. Biol. 2016, 22, 990-1007. [CrossRef] [PubMed]

53. Sadhra, S.S.; Wheatley, A.D.; Cross, H.J. Dietary exposure to copper in the European Union and its assessment for EU regulatory risk assessment. Sci. Total Environ. 2007, 374, 223-234. [CrossRef] [PubMed]

54. Damalas, C.A.; Eleftherohorinos, I.G. Pesticide Exposure, Safety Issues, and Risk Assessment Indicators. Int. J. Environ. Res. Public Health 2011, 8, 1402-1419. [CrossRef] [PubMed]

55. Li, Z.; Jennings, A. Worldwide Regulations of Standard Values of Pesticides for Human Health Risk Control: A Review. Int. J. Environ. Res. Public Health 2017, 14, 826. [CrossRef] [PubMed]

56. Jardim, A.N.O.; Caldas, E.D. Exposição humana a substâncias químicas potencialmente tóxicas na dieta e os riscos para saúde. Quím. Nova 2009, 32, 1898-1909. [CrossRef]

57. Conway-Gomes, K. Market integration, perceived wealth and household consumption of river turtles (Podocnemis spp.) in eastern lowland Bolivia. J. Latin Am. Geogr. 2008, 7, 85-108. [CrossRef]

58. Rodrigues, M.J.J.; Cardoso, E.C.; Cintra, I.H.A.; Souza, R.F.C. Morfometria e rendimento de carcaça de tartaruga-da-amazônia, Podocnemis expansa (Schweigger, 1812) em ambiente natural. Rev. Ciênc. Agrár./Amazon. J. Agric. Environ. Sci. 2016, 43, 161-168.

59. Luz, V.L.F.; Stringhini, J.H.; Bataus, Y.S.L.; Fernandes, E.S.; Paula, W.A.; Novais, M.N.; Reis, I.J. Rendimento e composição química de carcaça da tartaruga-da-Amazônia (Podocnemis expansa) em sistema comercial. Rev. Bras. Zootec. 2003, 32, 1-9. [CrossRef]

(C) 2018 by the authors. Licensee MDPI, Basel, Switzerland. This article is an open access article distributed under the terms and conditions of the Creative Commons Attribution (CC BY) license (http:/ / creativecommons.org/licenses/by/4.0/). 